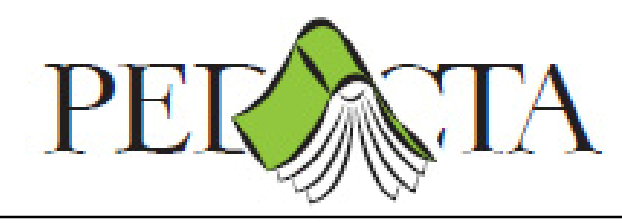

\title{
VIRTUÁLIS TANULÓKÖRNYEZETBEN HASZNÁLT KULCSKÉPESSÉGEK VIZSGÁLATA SZÓASSZOCIÁCIÓS MÓDSZERREL
}

\author{
STUDY OF CORE SKILLS USED IN A VIRTUAL \\ LEARNING ENVIRONMENT WITH WORD \\ ASSOCIATION METHOD
}

\begin{abstract}
Kristóf Zsolt
Abstract: Nowaday's information society no longer can and does not even want to imagine their everyday life without using the Internet. However, it cannot be said that everyone is ready to be able to absorb knowledge independently. Second Life is one of the most popular virtual environments which becomes the inevitable space for lifelong learning. We see open, sincere and growing motivation towards learning processes that have helped with the opportunities of virtual environments. This is reinforced by the active involvement of both the teacher and the students, which is almost automatically required in the processes. At the University of Debrecen, I launched a course in 2018 to test and transfer ten virtual core skills required for effective knowledge and use of Second Life.

During my research I carried out a word association study, considering that the above mentioned method is suitable for getting to know the students' knowledge structure and for exploring the ideas contained therein. The word association test showed a stronger correlation between walking and running, search and age based search, and mapping based pairs of skills. In addition, based on the results, the ten virtual key skills were divided into two completely separate groups. In the course of developing educational processes in virtual environments, transferring and practicing core skills is definitely recommended independently of the curriculum.
\end{abstract}

Keywords: Second Life, virtual learning environment, core skills, Word Association Method

\section{Bevezetés}

Napjaink információs társadalma már nem tudja és nem is akarja elképzelni mindennapjait az internethasználat nélkül. Ezzel együtt nem mondható ki az, hogy mindenki készen állna arra, hogy a tudást önállóan legyen képes magáévá tenni. A Second Life az egyik legnépszerübb virtuális tér. Többek között Keelan és munkatársai határozták meg azokat az előnyöket, amelyeket a virtuális világok a hagyományos területekhez képest biztosítani tudnak. Ezeket a következöképpen foglalták össze:

A virtuális terek használata képes eltörölni a fizikai-földrajzi határokat olyan szituációkban, ahol a kutatást végző személyek és a vizsgálni kívánt embercsoport egymástól messze található a fizikai térben.

A különböző médiacsatornák együttes felhasználásával, keverésével csökkenthetők a költségek.

Akár érzékenyebb, kényesebb témákat is állíthatunk a beszélgetés fókuszpontjába. Az anonimitást az avatárokon (a virtuális térben irányítandó entitásokon) keresztül használhatjuk fel. 
Összekapcsolhatunk olyan személyeket, akik különböző érdeklődésüek és a virtuális tér nélkül egymással csak kis valószínüséggel kommunikálnának (Keelan, Ashley, Morra, Busch, Atkinson és Wilson, 2015).

A Debreceni Egyetemen 2018-ban szabadon választott kurzust indítottam, amelyet nyolcvan hallgató kívánt teljesíteni, és amelynek keretében tíz virtuális alapképesség tesztelésére és átadására került sor. A képességek a Second Life hatékony ismeretéhez és használatához voltak szükségesek. Kutatásaim során szóasszociációs vizsgálatot készítettem, figyelembe véve, hogy a fent említett módszer alkalmas a hallgatók tudásszerkezetének megismerésére és az abban szereplő ötletek feltárására.

A szóasszociációs vizsgálat erősebb összefüggést mutatott a gyaloglás és a futás, a keresés és az életkoron alapuló keresés, valamint a térképhasználat alapú képességpárok között. A fentieken túl az eredmények alapján a tíz virtuális képességet két teljesen különálló csoportra sikerült osztani.

\section{Szakirodalmi áttekintés}

\subsection{A Second Life világa}

Oktatási folyamatok végrehajtása magyarázat és segítségnyújtás nélkül nehezen képzelhető el. Mindez nemcsak a valós térben történő tanítási-tanulási folyamatokra igaz, hanem a virtuális világban folyó oktatás esetében is. Gamage és munkatársai kutatásuk során alanyaikat aszerint különböztették meg, hogy azok mennyire voltak a virtuális terek használatában tapasztaltak. A csoportok véleménye eltért abban, hogy mennyire valószínü az érzelmi kapcsolat kialakulása tanuló és tanár között, viszont a csoportok egyetértettek abban, hogy a platformok használata elönyt jelent a tanulás során. Azt is hasonlóan látták, hogy a virtuális valóságok oktatási hasznosítása egyre szélesebb körben ajánlott, és főleg a félénkebb diákok találhatják meg benne a nyilvánvaló előnyöket (Gamage, Tretiakov és Crump, 2011). Hammick és Lee vizsgálta is a félénkebb, visszahúzódóbb felhasználókat és azt a következtetést tudták levonni, hogy a fenti típusú személyek kevésbé találják magukat kényelmetlen szituációkban virtuális térben, ellentétben a mindennapok helyzeteivel. Mindez nem jelentette feltétlenül azt, hogy elkezdtek jobban bízni kommunikációs képességeikben, de az mindenképpen igaz volt, hogy a kommunikációs körülmények megértésében segítették őket a virtuális térben alkalmazott lehetőségek (Hammick és Lee, 2014).

A Second Life virtuális tere az élethosszig tartó tanulás megkerülhetetlen színterévé kezd válni. A virtuális tér lehetőségeivel segített tanulási folyamatok felé nyílt, őszinte és növekvő motivációt lehet érzékelni, ezt tovább erősíti a folyamatokban szinte automatikusan megkövetelt aktív részvétel mind a tanár, mind a tanulók részéröl (Aristeidou és Spyropoulou, 2015).

A hagyományos tanítási-tanulási szokásokat a virtuális világok használata visszafordíthatatlanul megváltoztatta. Megfelelő körülményekkel rendelkeznek egy kezdő tanuló számára is, hiszen több előnyük van: alacsony költségü, jó minőségü, távolból is elérhető, biztonságos, fejlett a digitális környezet. Hatással vannak a tanulók önmenedzselési képességeire, növelik a gyakorlatorientált feladatokban való részvételüket, erősítik az értelmi fejlődést (Pellas, Kazanidis, Nikolaos és Georgia, 2016).

Greenwald és kollégái két nagy kategóriába rendszerezték a virtuális tanulókörnyezeteket az általuk biztosított előnyök szerint. Az első kategóriába tartoznak azok a terek, amelyek segítségével a felhasználók az egymás közötti kölcsönhatásokra fókuszálhatnak, míg a másik kategóriában olyan terek vannak, amelyekre nézve maga a környezet garantálja az egyedi lehetőségeket (Greenwald, Kulik, Kunert, Beck, Fröhlich, Cobb, Parsons, Newbutt, Gouveia, Cook és Snyder, 2017). Az általam elkészített tanulókörnyezet, melynek kialakításakor figyelembe vettem, hogy a képességek szintjét mérő feladatok egymásra épüljenek, a megjelenés pedig felhasználóközpontú legyen (Santos és Boticario, 2015) a második kategóriába sorolandó. 


\subsection{Szóasszociációs vizsgálatok Magyarországon}

Revákné Markóczi Ibolya és Tóth Zoltán 2015-ben adta ki Osztálytermi kutatás címü könyvét. Kiváló segédletet kapunk ebből a munkából, még akkor is képesek lehetünk véghezvinni egy szóasszociációs vizsgálatot, ha korábban ezt a kutatási technikát nem is alkalmaztuk. A fogalmak, hívószavak kiválasztása során ajánlott olyanokat alkalmazni, amelyek egy jól körülhatárolható tudástér elemeit képezik. Erre azért kell figyelni, mert ilyen tervezés esetén van arra esélyünk, hogy a hívószavakra közös asszociációkat kapjunk. Pozitívum, ha nemcsak azonos szófajokból áll a hívószavak listája. A hívószavak számát három és tíz közé szokás elhelyezni, habár felső határ nincs megállapítva. A vizsgálatot leggyakrabban írásban szokás elvégezni. A kiválasztott hívószavakat - véletlenszerủ módon - annyi lapra írjuk fel, ahány fös a vizsgált mintánk. A tanulók leggyakrabban egy percet kaphatnak arra, hogy a lap tetején olvasható hívószóval kapcsolatos asszociációikat egymás alá a lapra felírják. Az idő letelte után át kell lépni a következő lapra és a következő hívószóra, visszalapozni pedig nem szabad. A válaszok kiértékelését tanulónként kell elvégezni. A hívószavakra kapott asszociációkat páronként összehasonlítjuk. A több fogalmat tartalmazó lista első fogalma kapja a legnagyobb rangszámot. Ez maga a hívószó lesz. Az ide tartozó többi fogalom egyre csökkenő rangszámot kap, és a legutolsó asszociáció kapja az egyes rangszámot. Ugyanígy kell eljárni a másik fogalomhoz tartozó lista esetén is, de a rangszámok kiosztását itt is az előbbi rangszámmal kezdjük, mert a két lista viszonylatában a leghosszabb lista ennyi fogalmat tartalmaz. Ennek megfelelően a hívófogalom fogja kapni a legnagyobb rangszámot, majd egyre csökkenő rangszámok következnek. Ezután a két listában közösen előforduló fogalmak rangszámait páronként összeszorozzuk és összegezzük, végül elosztjuk a teljes egyezésnek megfelelő szorzatösszeg eggyel csökkentett értékével. Az így kapott hányados természetszerüleg 0 és 1 közé fog esni, és értéke minél nagyobb, annál szorosabb kapcsolat van a két vizsgált hívófogalom között. Ez a hányados, a kapcsolati együttható (relatedness coefficient, RC) jellemzi a két hívó fogalom közötti kapcsolat erősségét (Revákné Markóczi és Tóth, 2015).

2009-ben Kluknavszky Ágnes és Tóth Zoltán környezeti kémiával kapcsolatos kutatás program részeként alkalmazott szóasszociációs tesztet különböző korú tanulók levegőszennyezéssel kapcsolatos fogalmi rendszerének vizsgálatában. Általános- és középiskolás tanulók savas esővel, üvegházhatással és ózonréteg elvékonyodásával kapcsolatos fogalmait monitorozták. Az eredmények azt mutatták, hogy az aktuális tananyag erősebben, frissebben mutatkozott meg a tanulók fogalmi hálójában. Az életkor előrehaladtával a hívófogalmak kapcsolata egyre erősebb lett, és egyre pontosabb és több, a tudományos ismereteket egyre jobban megközelítő válaszszavakat produkáltak a gyerekek. A természettudományos elképzeléseknek nem megfelelő asszociációk használata abban segített, hogy sikerült felszínre hozni a tanulók e témakörben meglévő tévképzeteit. A szóasszociációs tesztet a kutatók alkalmasnak találták különböző tanulócsoportok tudásszerkezetének összehasonlítására és a fogalmi fejlődés kimutatására (Kluknavszky és Tóth, 2009).

Kovács László, Orosz Katalin és Pollner Péter 2012-es kutatási tevékenysége a különleges nevü Agykapocs-projekt megalkotását célozta. Az asszociációs adatgyüjtéshez felhasználták a jelenkor lehetőségeit. Szóasszociációs adatokat gyüjtöttek internethasználóktól, az asszociációk megadásában bárki részt vehetett. A felhasználónak mindenekelőtt regisztrálnia kellett a rendszerben azért, hogy bizonyos statisztikai adatokat megadjon. A kutatók eredményként fogalmazták meg azt, hogy a hálózatelméleti vizsgálati módszerek segítségével ki tudták mutatni, hogy az asszociációkból létrehozott adatbázis hálózata elsősorban kisvilág-karakterü és skálafüggetlen jellemzőket hordoz. Különbséget tapasztaltak nők és férfiak asszociációs hálózatainak vizsgálata során, valamint azt is megállapították, hogy a szorosan összekapcsolt csoportok gyors válaszai a csoportok közös elemei (Kovács, Orosz és Pollner, 2012).

Kovács László 2013-as munkájában föként a mentális lexikon témakörét vizsgálja. A teljesség igénye nélkül a következőket állapította meg erről a fogalomról. A mentális lexikon kutatása a pszicholingvisztika kutatási területei közé tartozik. A mentális lexikonnak, más szavakkal agyi szótárnak a beszédprodukciós és beszédpercepciós folyamatokban egyaránt szerepe van. Egyes kutatók szerint a mentális lexikon nem is egy meghatározandó fogalom, hanem egy metafora, és ebből következik, hogy meghatározása akár félrevezető is lehet. A mentális lexikon kutatása általában nem önmagában történik, hanem valamilyen aktivitással van kapcsolatban. A lexikon kifejezés vagy a 
szótárként való meghatározás már önmagában zavaró, hiszen egy szótár nem aktív, hanem passzív tárgy. A szerző arra a következtetésre jutott, hogy igen lényeges a mentális lexikonnal kapcsolatban annak dinamikusságát, időbeni változását kihangsúlyozni (Kovács, 2013).

Malmos Edina és Revákné Markóczi Ibolya 2015-ben a biológia témakörében alkalmazta a szóasszociációs technikákat. Vizsgálatuk elsődleges célja a tanulók konkrét fogalmakhoz kapcsolódó, tipikusan biológiai tévképzeteinek feltérképezése volt. A kutatást hetedikes és nyolcadikos általános iskolások részvételével folytatták le. A szerzők úgy találták, hogy a szóasszociációs módszer alkalmas a tanulók tudásszerkezetének megismerésére, az abban jelen lévő zavaró tévképzetek feltárására. Rátaláltak azokra a fogalmakra, amelyeknek nem sikerült beágyazódni a tanulók belső értelmező rendszerébe, lokalizálták azokat a területeket, amelyekhez kapcsolódó ismereteknek az elsajátítása nem volt megfelelő. Arra jutottak, hogy a tévképzetes asszociációk viszonylag gyengén kapcsolódnak a tudományos fogalmakhoz, a tanulók nehezen tudják azokat megérteni (Malmos és Revákné Markóczi, 2015).

Sójáné Gajdos Gabriella és Tóth Zoltán tanulmánya általános iskolai és gimnáziumi tanulók levegőszennyezéssel kapcsolatos tudásszerkezetét vizsgálta szóasszociációs módszerrel. 7-12. évfolyamos általános iskolai és gimnáziumi tanulók levegőszennyezéssel kapcsolatos fogalmainak hálózatát kívánták feltárni a szerzők. Eredményül azt kapták, hogy az egyes hívószavakhoz kapcsolódó asszociációs hálók többnyire a 9-10. évfolyamig gazdagodnak, majd ezután vagy stagnálás, vagy pedig csökkenés mutatkozik az asszociációk számában és gyakoriságában. A hívófogalmakra adott közös asszociációk alapján megrajzolt fogalmi hálóban is hasonló jellegzetesség volt megfigyelhető. Találtak tévképzetre utaló kapcsolatokat is. A fogalmi hálókban a tartalmilag helyes kapcsolatok mellett felbukkantak a következő fogalmi megértési zavarra utaló kapcsolatok: üvegházhatás- ózonlyuk, savas eső-ózonlyuk, savas eső- üvegházhatás (Sójáné Gajdos és Tóth, 2017).

\section{Kutatási paraméterek, kutatási módszerek}

\subsection{Tanulókörnyezet és virtuális képességek}

A Debreceni Egyetemen 2018-ban szabadon választott kurzust indítottam, amely a Second Life hatékony kezelési ismereteihez szükséges virtuális alapképességek vizsgálatát és átadását célozta meg. A tárgy oktatása teljes egészében virtuális térben, általam kialakított virtuális tanulókörnyezet és ugyanitt elhelyezett virtuális tanulástámogató eszközök segítségével történt. Az elkészült tanulókörnyezetet az 1. ábrán szemléltetem.

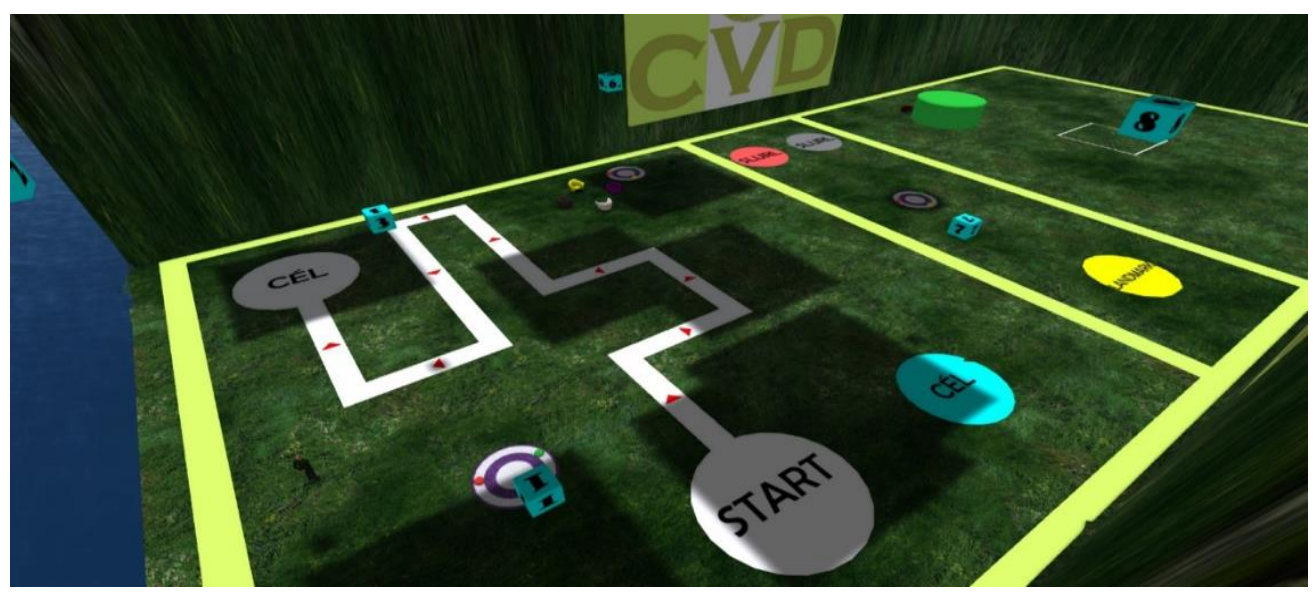

1. ábra: A kutatás virtuális tanulókörnyezete a Second Life-ban

A virtuális térben használt kulcsképességek csoportját tíz olyan képesség alkotja, amelyeket tapasztalataim alapján - számos esetben kell használniuk a felhasználóknak. A képességeket az általam korábban megalkotott és publikált Second Life-alapú csomagból válogattam, az alapvetőbb, bevezető 
típusú képességekre koncentráltam (Ollé és Kristóf, 2014). Ezek a következők voltak: séta, futás, repülés, leülés, teleportálás, minitérkép kezelése, világtérkép kezelése, keresés, korosztályos keresés, kameramozgatás. A hallgatóknak a fenti tíz képességhez kapcsolódó feladatokat kellett megoldani a virtuális térben.

A virtuális kulcsképességekkel kapcsolatosan szóasszociációs vizsgálatot végeztem. A tíz vizsgált képesség nevei voltak a hívószavak, ezekkel kapcsolatban kértem nyolcvan hallgató véleményét. A hívószavakat véletlenszerủ sorrendben kapták meg a tanulók, egy percnyi idejük volt arra, hogy szavakat írjanak le az adott képességgel kapcsolatban. A vizsgálatot internet segítségével vittem végbe, egy olyan szolgáltatás segítségével, ami biztosította a szavak írásakor az egy perc limitidőt. Összesen 2479 szó érkezett. A tíz képességet minden lehetséges módon párosítva negyvenöt különböző képességpárt vizsgáltam meg a nyolcvan hallgató esetében. Így összesen 3600 összehasonlítást kellett megtennem. A problémamegoldást úgy gyorsítottam, hogy az egy hallgatóhoz tartozó összes szóra nézve online applikáció segítségével kigyüjtöttem a többször előforduló szavakat. Természetesen figyeltem arra, hogy az egyes elnevezések is előfordulhattak más képességekhez kapcsolódva. Miután ez megtörtént, csak azokat a szavakat kellett vizsgálnom, amelyek többször is előfordultak egy adott hallgató válaszaiban.

\subsection{Kutatási kérdések}

Kutatásom során szóasszociációs vizsgálat segítségével kerestem a választ arra a kérdésre, hogy vannake, és ha igen, milyen erősségüek az egyes képességek közötti kapcsolatok.

Kutatási kérdéseimet a következőképpen fogalmaztam meg.

Mely képességek között van erősebb és melyek között gyengébb kapcsolat a szóasszociációs vizsgálat szerint?

Kialakíthatók-e a tíz virtuális kulcsképesség között további csoportok a szóasszociációs vizsgálat eredményeiből adódó kapcsolatok erősségének alapján?

Milyen jellegü szógyakoriság kapcsolható az egyes virtuális kulcsképességekhez? Vannak-e különlegesen sokszor megjelenő szavak?

\subsection{Alkalmazott módszerek}

A felhasználók a kapcsolatfelvételt, illetve a Second Life keretrendszerének letöltését, installálását és elindítását követően egy szöveges bevezetőt kaptak, amiben röviden felvázoltam, hogy mi vár rájuk a feladatmegoldások során. Ezután beléphettek a virtuális tanulókörnyezet területére és képességenként megkapták az egyes feladatokat, amelyek megoldására öt percet kaptak.

Az első vizsgált képesség a séta volt, a tanulókörnyezetben egy kijelölt útvonalon kellett végighaladniuk a felhasználóknak az avatárjukkal. Felhívtam a figyelmüket arra, hogy lehetőleg minél kevesebbszer térjenek le az ösvényről. A futás felmérése során ugyanez nehezebben volt kivitelezhető, hiszen gyorsabban kellett megtenniük az utat. Az útvonal képe a 2. ábrán látható.

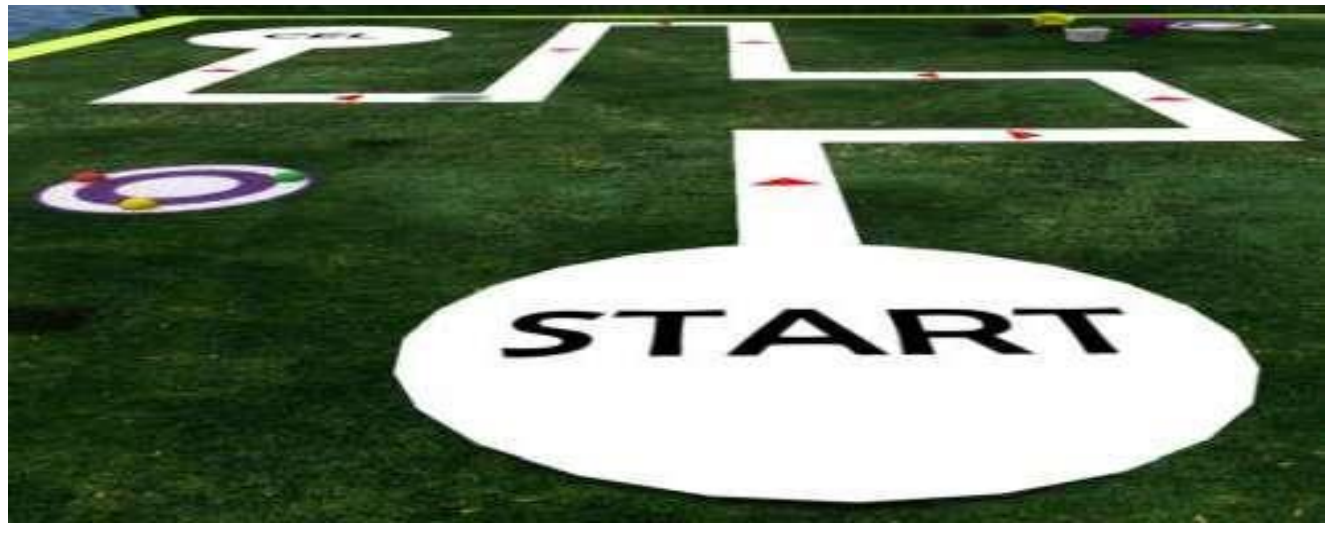

2. ábra: A séta és futás képességek mérését megvalósító virtuális eszköz 
A repülés nevü képesség elemzésekor a tanulóknak háromdimenziós útvonalon kellett a kurzorgombok segítségével végighaladniuk, míg a teleportálás képessége alkalmazásakor ugyanezt az egér jobb gombjának használatával és a teleport opció kiválasztásával tették meg. A leülés képességével kapcsolatos feladatpárban az ülés opciót sajátíthatták el a résztvevők, a megfelelő foteleket adott sorrendben használva. A világtérképen történő kereséssel tudtak választ adni a résztvevők arra a kérdésre, hogy az egyes - kérdésekben szereplő - szigeteknek mi az elnevezésük, míg a minitérkép használatával arra kellett választ adni a tanulóknak, hogy egy adott szigeten, egy adott pillanatban éppen hányan tartózkodnak. Külön vizsgáltuk a Second Life általános keresési funkcióit, valamint a korosztályos keresést, végül pedig a kameramozgatási képességeikről adtak számot a hallgatók, melynek során egy átlátszatlan hengerben található kocka színét kellett megállapítani.

\section{Eredmények}

\subsection{A szóasszociációs vizsgálat eredményei}

Az eredmények érdekes tényezőkre világítottak rá. Mindenekelőtt, a leglényegesebb megállapításként tudom megfogalmazni, hogy a képességpárok közötti átlagos erősségek alapján a tíz kulcsképesség teljesen diszjunkt módon két csoportba rendeződött. Az egyik csoportba a séta, futás, repülés, leülés, teleport, kameramozgatás képességeket tudtam sorolni, a másikba pedig a további négy, a minitérkép, világtérkép, keresés és korosztályos keresés kerültek. Az első csoportnak a mozgás típusú virtuális kulcsképességek nevet adtam, hiszen mindegyik képesség kapcsolódott a mozgás folyamatához. A másik csoport a keresés típusú virtuális kulcsképességek nevet kapta, hiszen az ebbe a csoportba tartozó négy képesség a keresés tevékenységhez kötődött. Ezen két csoportba tartozó alcsoportokat ajánlott külön-külön oktatni, érdemes a sorrendet is úgy megválasztani, hogy az erősen kötődő párok egymás után kerüljenek bemutatásra.

A legerősebb kötődés a séta-futás, a keresés-korosztályos keresés és a minitérkép-világtérkép párok között mutatkozott. Mindhárom esetben nyilvánvaló az ok, a képességpárok képviselőit lényegileg hasonló tényezők alkotják. A séta és a futás esetében az útvonal, a keresés és a korosztályos keresés tekintetében magának a keresésnek az elsődleges alkalmazása, a minitérkép és a világtérkép vonatkozásában pedig a térképhasználat testesítette meg a közös nevezőt. Közepes erősségü kapcsolatot mértem a repülés-teleport, a keresés-minitérkép és a keresés-világtérkép párok között. A keresés és a minitérkép valamint a keresés és a világtérkép közötti kötődés nem volt meglepő, hiszen a térképek kezelésekor valójában speciális keresést folytatnak le a felhasználók. A repülés és a teleport közötti kapcsolat viszont váratlanul ért. A virtuális térben kevéssé jártas személy érezheti úgy, hogy a fenti két képesség összetartozik, de a valóságban ez nincs így. Repüléskor a három dimenzió lehetőségeit teljesen kihasználva aktívan irányítjuk avatárunkat, ahogy a séta és a futás alkalmazásakor. Teleportálás esetén viszont passzívan követjük az előre beállított paramétereket és avatárunk a beállítási adatok alapján materializálódik a célkoordinátákon. Tovább gondolkodva, a két képesség közötti kapcsolaton, a gyorsaság tényezője került előtérbe. Mindkettő használatakor gyorsan tudunk nagyobb távolságokat megtenni, a felhasználókat ez a tény sarkallhatta arra, hogy hasonló szavakat írjanak a két képesség neveinek hívószavaira.

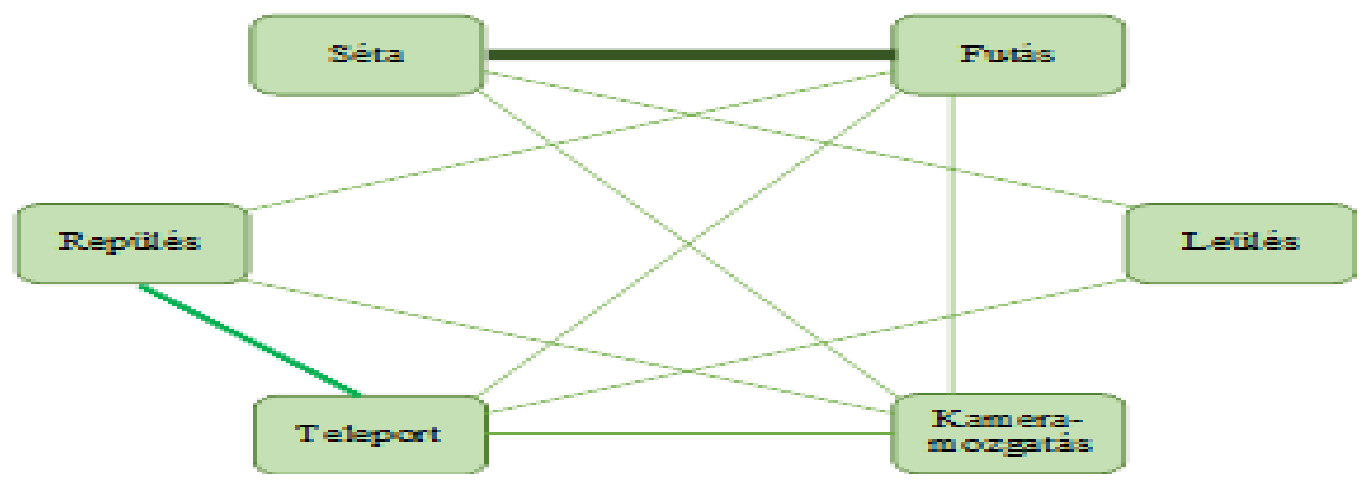

3. ábra: A mozgás típusú virtuális kulcsképességekre vonatkozó hívószó-párosítások átlagolt eredményei 
A 3. és a 4. ábrán láthatóak a további említésre méltó kapcsolatok, a két csoport képviselőit azért tudtam külön ábrákon bemutatni, mert a csoportok szereplöi között érdemleges kapcsolat nem volt. Az 1 . táblázatban szemléltettem azt, hogy milyen vastagságú szakaszokkal jelöltem az egyes intervallumokhoz tartozó kapcsolatok erösségeit.

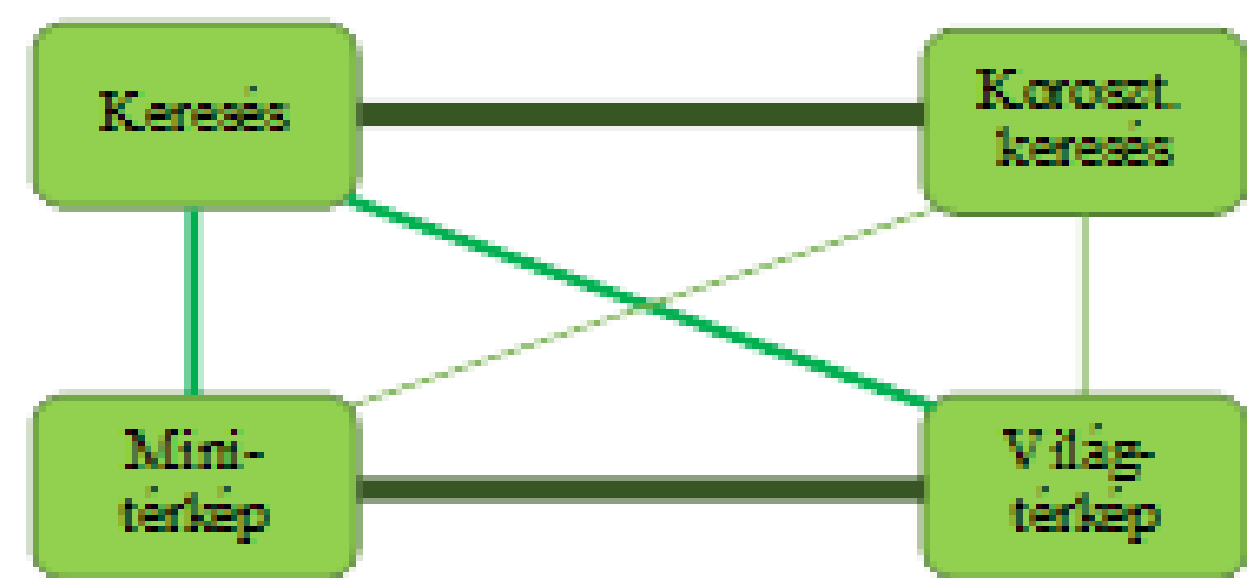

4. ábra: A keresés típusú virtuális kulcsképességekre vonatkozó hívószó-párosítások átlagolt eredményei

1. táblázat: A 3-as és 4-es ábrán látható hívószó-párosítások eredményeihez tartozó jelmagyarázat

\begin{tabular}{|l|l|}
\hline $\begin{array}{l}\text { A kapcsolat } \\
\text { erőssége }\end{array}$ & A kapcsolat erósségének szemléltetése \\
\hline $0,000-0,018$ & \\
\hline $0,019-0,036$ & \\
\hline $0,037-0,054$ & \\
\hline $0,055-0,072$ & \\
\hline $0,073-0,090$ & \\
\hline $0,091-0,108$ & \\
\hline
\end{tabular}

A 2. táblázatban az összes képességpárhoz tartozó összesített átlageredményeket láthatjuk. A negyvenöt érték közül sötétzölddel jelöltem a legnagyobbakat, amelyek a legerösebb kapcsolatokat jelezték. Világosabb zölddel szemléltettem a közepesen erős összefüggéseket. A táblázatot vizsgálva szembetűnő, hogy a kiemelt értékek a föátló mentén, de legalábbis annak közelében helyezkednek el. Ez alátámasztja a kutatásomban alkalmazott képességsorrendet, hiszen az erős kapcsolatot hordozó párokat egymás után, de legfeljebb egy képesség tanulmányozásának közbeiktatásával vizsgáltam. A jövőre nézve is ajánlható az alkalmazott sorrend, annyi kiegészítéssel, hogy a kameramozgatás képességet célszerü a mozgáshoz tartozó csoporton belül oktatni, hiszen mozgás típusú virtuális kulcsképességek csoportjához tartozó készségről van szó.

2. táblázat: Az egyes párosítások átlagolt eredményei

\begin{tabular}{|l|l|l|l|l|l|l|l|l|l|l|}
\hline & Séta & Futás & Repülés & Leülés & Teleport & $\begin{array}{l}\text { Mini- } \\
\text { térkép }\end{array}$ & $\begin{array}{l}\text { Világ- } \\
\text { térkép }\end{array}$ & Keresés & $\begin{array}{l}\text { Koroszt. } \\
\text { keresés }\end{array}$ & $\begin{array}{l}\text { Kamera- } \\
\text { mozg. }\end{array}$ \\
\hline Séta & & & & & & & & & & \\
\hline
\end{tabular}




\begin{tabular}{|l|l|l|l|l|l|l|l|l|l|l|}
\hline Futás & 0,099 & & & & & & & & & \\
\hline Repülés & 0,014 & 0,030 & & & & & & & & \\
\hline Leülés & 0,030 & 0,013 & 0,011 & & & & & & & \\
\hline Teleport & 0,012 & 0,023 & 0,063 & 0,029 & & & & & & \\
\hline $\begin{array}{l}\text { Mini- } \\
\text { térkép }\end{array}$ & 0,007 & 0,010 & 0,011 & 0,006 & 0,015 & & & & & \\
\hline $\begin{array}{l}\text { Világ- } \\
\text { térkép }\end{array}$ & 0,002 & 0,006 & 0,008 & 0,002 & 0,017 & 0,103 & & & & \\
\hline Keresés & 0,001 & 0,012 & 0,009 & 0,011 & 0,010 & 0,072 & 0,067 & & & \\
\hline $\begin{array}{l}\text { Koroszt. } \\
\text { keresés }\end{array}$ & 0,001 & 0,005 & 0,002 & 0,001 & 0,004 & 0,022 & 0,022 & 0,106 & & \\
\hline $\begin{array}{l}\text { Kamera- } \\
\text { mozg. }\end{array}$ & 0,020 & 0,029 & 0,024 & 0,013 & 0,023 & 0,006 & 0,009 & 0,013 & 0,010 & \\
\hline
\end{tabular}

\subsection{A kulcsképességekhez kapcsolt szavak gyakoriságai}

A szóasszociációs vizsgálat során a képességekhez, mint hívószavakhoz a nyolcvan résztvevő számos szót kapcsolt. A 3. táblázatban a felhasználók által beérkezett szavak összesített táblázatát látjuk, melyben a legkiemelkedőbb gyakoriságú szavak szerepelnek. A táblázatban csak azokat a szavakat jelenítettem meg, melyek legalább tizenkétszer fordultak elö, ezzel kiszürve azokat a szavakat, amelyeket csak néhányszor említettek meg.

3. táblázat: A beérkezett szavak összesített gyakorisági előfordulása legalább tizenkét előfordulás esetén

\begin{tabular}{|l|l|l|l|l|l|}
\hline sorszám & szó & mennyiség & sorszám & szó & mennyiség \\
\hline 1. & nehéz & 38 & 15. & ember & 17 \\
\hline 2. & pihenés & 34 & 19. & kocka & 15 \\
\hline 3. & találat & 33 & 19. & mozgás & 15 \\
\hline 4. & utazás & 32 & 19. & hely & 15 \\
\hline 5. & tájékozódás & 30 & 19. & szám & 15 \\
\hline 6. & kutatás & 27 & 19. & google & 15 \\
\hline 7. & érdekes & 26 & 24. & kezdés & 14 \\
\hline 8. & sziget & 23 & 24. & lassú & 14 \\
\hline 8. & gyors & 23 & 26. & segítség & 13 \\
\hline 8. & szabadság & 23 & 26. & indulás & 13 \\
\hline
\end{tabular}




\begin{tabular}{|l|l|l|l|l|l|l|}
\hline 11. & könnyú & 22 & 26. & hasznos & 13 \\
\hline 11. & térkép & 22 & 26. & kényelem & 13 \\
\hline 11. & gyorsaság & 22 & 30. & látótér & 12 \\
\hline 14. & információ & 19 & 30. & vonal & 12 \\
\hline 15. & világ & 17 & 30. & balra & 12 \\
\hline 15. & fotel & 17 & 30. & beszélgetés & 12 \\
\hline 15. & szín & 17 & 30. & egyenes & 12 \\
\hline
\end{tabular}

A „nehéz” szót a szóasszociációs vizsgálat során harmincnyolcszor használták, ez volt a leggyakoribb, mely máris felhívja a figyelmet a kutatás során általam tapasztalt egyik legfontosabb következtetésre, miszerint a virtuális környezetek használata egy új felhasználó számára nem magától értetődő. Tehát ha szeretnénk virtuális környezeteket bevonni az oktatásba, érdemes a hallgatókat felkészíteni annak használatára, bemutatni az alapvető funkciókat, hogy minél kevesebb tényezö terelhesse el a figyelmet az oktatási anyagról a tanulás során, a tanulók pedig ne ijedjenek meg az új környezettől. A második szótól kezdve leginkább az egyes feladatokra vonatkozó benyomások tükröződnek, és nem annyira a környezet egészére vonatkozó tapasztalatok. Ezeket a szavakat az egyes képességekre nézve külön elemzem, így itt inkább az általánosabb szavakra koncentrálok.

Általánosnak tekinthető a „kutatás” szó, mely a hatodik helyen szerepel, huszonhét fö alkalmazta. A hallgatókat tájékoztattam arról, hogy egy kutatásban vesznek részt, így valószínüleg ezért használhatták ezt a szót többen is. Kiemelkedő még a "gyors" szó a hetedik helyen, illetve ehhez kapcsolódóan a „gyorsaság” szó a tizedik helyen, mely lényegében ugyanazt a jellemzőt takarja. Ezen szavak a környezet gyorsaságára utalhatnak, hiszen lényegesen gyorsabban adhatók át egy ilyen környezetben az információk, mint a valós térben, ahol a tananyaggal töltött idő mellett rengeteg idő mehet el akár odavissza utazásra is. A tizenharmadik helyen az „információ” szerepel, melyet igen pozitívnak ítélek, hiszen több ember számára is fontos volt, hogy a teszt során információkhoz, tapasztalatokhoz juthatott. A tizennegyedik helyen az „ember” szó található, mely utalhat arra, hogy a virtuális tanulókörnyezet középpontjában gyakran maguk a felhasználók állnak, illetve az avatárokra, melyek segítségével megjelenítjük magunkat a virtuális térben. Fontos még a huszonharmadik helyen álló „érdekes” szó, mely bizonyítja, hogy a módszert többen is izgalmasnak találták, mely a kutatás szempontjából igen fontos, hiszen egy, a hallgatók által érdekesnek vélt módszerrel hatékonyabbá tehető az oktatási folyamat, az információ átadása. Azonban ugyanezen a helyen szerepel a „lassú” kifejezés is, melyből következtethető, hogy néhány felhasználó lassúnak vélte a folyamatot. Ez lehetett egyrészt a nem megfelelő hardverek miatt, másrészt azért is, mert a virtuális térben történő oktatási folyamat különlegességéből, egyediségéből adódóan sem ajánlott mindenki számára. Ezt nem tekintem problémának, természetes tényezőnek vélem. A huszonhatodik szó a „segítség”, mely ismét rávilágíthat arra a tényre, hogy egy új felhasználó számára sokszor segítség kell a környezet használatához. Szintén huszonhatodik helyen szerepel a „hasznos” szó, mely igen fontos, hiszen többen is úgy vélték, hasznosak az ilyen környezetek, mely vonatkozhat egyrészt az oktatásba történő bevonásra, illetve arra, hogy fontos a virtuális tér használatának megtanítása.

Külön is megvizsgáltam az egyes képességekhez beérkezett szavak gyakoriságát. A sétával kapcsolatban a legtöbb felhasználónak a „lassú” szó jutott eszébe, hiszen a funkció lassabb módja a közlekedésnek a virtuális, illetve a valós térben is. Ezt a szót összesen tizenkétszer használták a képességre vonatkozóan. Ezzel szemben a futásra vonatkozóan a „nehéz” szó érte el az első helyet, szintén tizenkétszer használták, és a „gyors” szó a második helyet érte el, tizenegyszer fordult elő. Ez arra reflektál, hogy a futás opcióval jóval gyorsabban lehet közlekedni a virtuális térben, azonban az 
első helyen szereplő „nehéz” szó kiemeli, hogy a futást használva a gyorsaság miatt jóval nehezebb az avatárt irányítani, mint a sétával.

A repülés képességéhez tartozó szavak sorrendjének első helyén a „szabadság” szó szerepel, melyet a valós térre vonatkozóan is sokszor társítunk a repüléshez. A virtuális térben is igen fontos jellemzője a repülésnek a szabadság, hiszen itt már háromdimenzióban mozoghatunk avatárunkkal, így sok egyéb objektum is megközelíthetővé válik.

A leülés kulcsképességhez tartozó szavak közül a leggyakoribb a „pihenés” volt, hiszen a pihenés szorosan kapcsolódik az üléshez, ahogy a negyedik helyen szereplő „kényelem” is. A második és a harmadik leggyakoribb szó a „fotel” és a „szín” lett, ezek a tartalmazó feladathoz kapcsolódtak, hiszen megadott sorrendben kellett különböző színü fotelekbe ülni az avatárral, így gyakorolva a funkciót.

A teleportáláshoz tartozó szavak gyakorisági sorrendjének első helyén a „szám” szó szerepelt, mely a képesség bemutatását szolgáló feladathoz kapcsolódott, ahol számozott platformokra teleportálva tanulhatták meg a felhasználók a funkciót. Többször szerepelt az „utazás”, „helyváltoztatás”, „helyzetváltoztatás”, ,áthelyezés” szó is, melyek mind a virtuális térben való mozgásra utaltak. Fontos, hogy mind a „gyorsaság”, „gyors” szavak és a „könnyü” szó is szerepelt a szavak közt, amiből levonható az a következtetés, hogy ez az avatármozgatási forma nemcsak gyors, de könnyen használható egy új felhasználó számára is, melyet fontos figyelembe vennünk egy oktatási környezet megalkotása során.

A minitérképen és világtérképen történő keresés folyamata szorosan összekapcsolódik, az ezekkel kapcsolatban érkezett szavakat együtt vizsgáltam. A leggyakoribb szó a minitérképre vonatkozóan a „tájékozódás”, mely tizennégyszer szerepel. Ez érthető, hiszen a minitérképet nagyszerüen használhatjuk az adott szigeten való eligazodásra. Erre utal a „sziget” szó gyakori használata is. A két képesség szoros kapcsolatát mutatja, hogy a világtérkép tekintetében a két leggyakoribb a fenti két szó volt.

A keresés és korosztályos keresés képességekhez tartozó szavak gyakoriságát szintén összekapcsolva elemeztem. Mindkettőre vonatkozóan a „találat” szó volt a leggyakoribb, ami érthető, hiszen ez a szó alapfogalomként bukkan fel az internetes keresésekkel kapcsolatosan. A keresés vizsgálata esetében a „kutatás” szó szintén első helyen szerepelt. A „kutatás” a keresés szó szinonimája, pontosan ezért a korosztályos keresésnél is többször használták. Sokan megemlítették még a „google” szót, mely napjaink legtöbbet használt keresőoldalának neve, illetve az információ szót is, mely azt fejezi ki, hogy a képesség használata közben sok új információval gazdagodtak, megtudták, hogy a Second Life világára vonatkozóan hogyan tudnak még több adathoz jutni.

A kameramozgatásra vonatkozóan a leggyakrabban használt szó a „nehéz” volt, de ennek szinonimája, a „bonyolult” is többször szerepelt. Ezek arra utalnak, hogy a kameramozgatásra vonatkozó feladat nehéznek bizonyult az új felhasználók körében, és ezt mutatják a tesztelés során szerzett tapasztalataim is.

\section{5. Összefoglalás}

Szóasszociációs vizsgálatom arra derített fényt, hogy a tíz kulcsképesség teljesen különálló két csoportba rendeződött. A mozgás típusú virtuális alapképességek csoportjába hat, a keresés típusú virtuális alapképességek csoportjába négy képesség tartozott. A két csoportba tartozó alcsoportokat ajánlott külön oktatni, érdemes a sorrendet is úgy kialakítani, hogy az erősen kötődő képességpárok egymás után kerüljenek bemutatásra. A legerősebb kötődés a séta-futás, a keresés-korosztályos keresés és a minitérkép-világtérkép párok között mutatkozott.

A szógyakoriság alapú kutatás tekintetében a legtöbbször a „nehéz” elnevezést alkalmazták a hallgatók, melyből levonható az a következtetés, miszerint a virtuális környezetek használata egy új felhasználó számára egyáltalán nem tekinthető magától értetődőnek, érdemes időt fordítani az ismerkedésre. Jelentős mennyiségben szerepeltek a vizsgálatban a „gyors” és a „gyorsaság” szavak is, amelyek a környezet gyorsaságára utalhatnak, hiszen bizonyos esetekben az információk sebesebben adhatók át egy ilyen környezetben. Az „ember” szó utalhat arra, hogy a virtuális tanulókörnyezet középpontjában 
sokszor maguk a felhasználók állnak, illetve az avatárokra, amelyeken keresztül megjeleníthetjük magunkat a virtuális térben. Az „érdekes” szó, pedig azt bizonyítja, hogy a módszert többen is izgalmasnak, figyelemfelkeltőnek tartották, mely a kutatás szempontjából igen fontosnak mondható, mert a hallgatók által megragadónak érzett módszerrel hatékonyabbá tehető az oktatási folyamat, valamint ezen keresztül az információ átadása is.

\section{Irodalomjegyzék}

Aristeidou, M., Spyropoulou, N. (2015): Building Technology and Science Experiences in 3D Virtual World. Procedia Computer Science, 65, 259-268.

Gamage, V., Tretiakov, A., Crump, B. (2011): Teacher perceptions of learning affordances of multiuser virtual environments. Computers \& Education, 57(4), 2406-2413.

Greenwald, S.W., Kulik, A., Kunert, A., Beck, S., Fröhlich, B., Cobb, S., Parsons, S., Newbutt, N., Gouveia, C., Cook, C., Snyder, A. (2017): Technology and applications for collaborative learning in virtual reality. In Smith, B., Borge, M., Mercier, E., Lim, K. Y. (eds.): Making a Difference: Prioritizing Equity and Access in CSCL, 12th International Conference on Computer Supported Collaborative Learning. International Society of the Learning Sciences, Philadelphia, PA, USA, 719-726.

Hammick, J., Lee, M. (2014): Do shy people feel less communication apprehension online? The effects of virtual reality on the relationship between personality characteristics and communication outcomes. Computers in Human Behavior, 33, 302-310.

Keelan, J., Ashley, L. B., Morra, D., Busch, V., Atkinson, K., Wilson, K. (2015): Using virtual worlds to conduct health-related research: Lessons from two pilot studies in Second Life. Health Policy and Technology, 4(3), 232-240.

Kluknavszky, Á., Tóth, Z. (2009): Tanulócsoportok levegőszennyezéssel kapcsolatos fogalmainak vizsgálata szóasszociációs módszerrel. Magyar Pedagógia, 109(4), 321-342.

Kovács, L. (2013): Fogalmi rendszerek és lexikai hálózatok a mentális lexikonban. Tinta Könyvkiadó, Budapest.

Kovács, L., Orosz, K., Pollner, P. (2012): Magyar szóasszociációk hálózata. Magyar Tudomány, 173(6), 699-705.

Malmos, E., Revákné Markóczi, I. (2015): Biológia fogalmakhoz kapcsolódó tévképzetek vizsgálata szóasszociációs módszerrel. Iskolakultúra, 15/5-6, 190-199.

Ollé, J., Kristóf, Zs. (2014): Learning, Teaching and Developing in Virtual Education. Eötvös Kiadó, Budapest.

Pellas, N., Kazanidis, I., Nikolaos, K., Georgia, G. (2016): Exploring the educational potential of threedimensional multi-user virtual worlds for STEM education: A mixed-method systematic literature review. Education and Information Technologies, 22(5), 2235-2279.

Revákné Markóczi, I., Tóth, Z. (2015): Osztálytermi kutatás. Debreceni Egyetemi Kiadó, Debrecen.

Santos, O., Boticario, J. (2015): Practical guidelines for designing and evaluating educationally oriented recommendations. Computers \& Education, 81, 354-374.

Sójáné Gajdos, G., Tóth, Z. (2017): Általános iskolai és gimnáziumi tanulók levegőszennyezéssel kapcsolatos tudásszerkezetének vizsgálata szóasszociációs módszerrel. Magyar Kémikusok Lapja, LXXII(2), 44-49. 


\section{Szerző}

Kristóf Zsolt, Debreceni Egyetem, Egészségügyi Kar, Debreceni Egyetem, Bölcsészettudományi Kar, Nevelés- és Mủvelődéstudományi Doktori Program, Debrecen (Magyarország). Email: zsolt.kristof@gmail.com 